\title{
PAL/EOCLIMATES
}

A NATO advaneed study institute on "Palæoclimates" was held in King's College, Neweestle upon Tyne, organized jointly by the Departments of Physies and Geology, during January 7-12.

At the end of the conference, Prof. W. H. Bucher (Columbia University) emphasized the importance of this subject to the most recent of the major confrontations of geology and physics. Geology was first confronted with results from physics after Rutherford's discovery of the laws of radioactive decay, when it became possible by radiometric age determinations to test the chronological sequence of sedimentary strata based on palæontological and stratigraphical methods. The quantitative physical method confirmed this sequence in general and provided absolute ages. The second followed the development, by Vening Meinesz, of a method of measuring gravity at sea. This time the older geological notion, that continental and oceanic structures were similar and that oceanic areas might be foundered continents, was overturned. Subsequent surveys of the sea-floor have confirmed that the oceanic basins are fundamentally different from continental areas. The third great confrontation has occurred through the development of palæomagnetism, chiefly in England, ovor the past decade. These studies have yielded, within any one continent, self-consistent sets of data which have been held to show that continental displacements have occurred over the past 100 or 200 million years, that is, the past 5 per cent of the life of the Earth. This challenges the geologist to re-assess the geological arg'uments for continental drift.

One of the most obvious forms of geological evidence as to whether or not the continents have always been in their present positions comes from the study of ancient climates. The properties of a sedimentary rock depend partly on the environments of erosion, transport and deposition. A chief factor in these environments is the climate and climate is clearly related to latitude. As will appear later, the exact extent of this relationship is far from clear. None the less, if an ancient climatic régimo can be recognized and its latitudinal extent determined it provides an independent test of the latitude given by palæomagnetic studies. At the conference, although the palæomagnetic evidence was given only secondary consideration, the importance of its role underlay the whole meeting.

The more important topics critically reviewed during the course of the meeting were: (1) plant distribution in Crnozoic times; (2) conditions of formation of the late Palæozoic coals; (3) recognition and significance of glacial horizons; (4) indications of climate obtainable from palæontology; (5) determination of ancient temperatures by the isotope method; (6) indications of climate from chemical deposits; and (7) elimates of certain geological periods.

The Newcastle meeting was particularly valuable and significant because it was the first time that all the separate approaches to the single subject of ancient climates had been considered jointly by an assembly of scientists working in the different fields of geology, palæontology, palæobotany, meteorology, geophysies, pedology, and sedimentary petrology. As illustrations of the subjects and ideas brought forward at the meeting, three unrelated topies can be mentioned.

The first concerns modern views on glacial evidence. It seems from the paper by J. C. Crowell (University of California) and the subsequent discussion that a glaciated pavement, with a tillite resting on it, is the only safe evidence for an ancient glaciation. Of the many morphological and sedimentary features so distinctive of the Quaternary glaciation fow are likely to survive through a long geological history. This is evident even from the much softer topography of the 'Older Drift'. Although B. C. Heezen (Lamont Geological Observatory) was at pains to point out that there should be no confusion between turbidites and glacio-marine deposits, other deposits, such as those due to mud flows, can be and have been mistaken for tillites. They are sometimes called tilloids. Striations not of glacial origin can even occur in them, the older the deposit the more chance there is of tectonic activity producing striation.

The difficulties in correctly identifying ancient boulder beds as tillites were brought out in two papers both dealing with the same formation, the Granville Conglomerate of Normandy. The basic facts concerning this boulder bed are not in dispute, but their interpretation is vastly different. J. Dangeard (University of Caen) elaimed that the deposits were typical fluvio-glacial beds. Their association with flysch deposits was commented on by Dangeard, whose explanation was that glaciation, with lowered sea-level and increased amounts of mud being carried down into the sea, provided favourable conditions for turbidity currents. This point had previously been mentioned by Heezon. E. L. Winterer (University of California) agreed that these associated beds were turbidites, but considered that the so-called glacial horizons merely represented sub-aqueous mud-flow deposits due to slumping around the sides of the basin in which the turbidites were being deposited. None of the associated features--striæ, shape and other surface features of the pebbles, such as bipolar fractures, or the graded varve-like beds -was thought by Winterer to be diagnostic.

A paper by R. Maack (University of Parana), of which only the summary was available at the meeting, described Dovonian glacial deposits in South America, but a detailed analysis by $J$. J. Bigarolla (University of Parana) of one of these beds, the Furnas Sandstone, once again argued convincingly against a glacial origin of the included pebbles.

Thus the conference concluded that detailed petrographic and field studies of each reported glacial were needed, and each must be treated on its merits. Nevertheless, W. B. Harland (Sedgwick Museum, Cambridge) provoked considerable discussion by his suggestion of an exceedingly severe glaciation in late Precambrian timesmore severe than the Permo-Carboniferous glaciation of the southern hemisphere or the Quaternary Iee Agefor he claimed that $\theta$ ven allowing for mistaken identification of some beds as glacial, the evidence of late Precambrian glaciation is still remarkably widespread. This idea even provided M. J. S. Rudwick (University of Cambridge) with a possible explanation for the sudden appearance of comparatively advanced Metazoa in the Lower Cambrian. The evolutionary advance was made possible by the ecological and climatological changes at the disappearance of glaciation.

A second item of considerable interest concerned the modern palæontological approach. In the past, considerable use has been made of eertain key fossils as climatic indicators without sufficient attention being paid to the remainder of the associated faunal assemblage. At the conference speakers were careful to distinguish betwoen fossil assemblage and fossil community. The ecologists pointed out that following death the hard parts of some organisms, which can be considered as 'sedimentary material', may be transported and deposited with the members of an entirely different community existing in an entirely different ecological environment. There is, furthermore, a continual addition due to the 'rain' of remains of pelagic organisms. Thus, in any fossil assem. blage, it is necessary to separate the exotic and autochthonous elements. Attempts to obtain a quantitative measure have led to the idea of a diversity gradient. 
This is based on the observation that in certain large groups of organisms variety increases towards the equator, though in cooler latitudes a given species may be very abundant. The diversity gradient is not entirely dependent on temperature so that anomalies can occur, and it is important that the diversity need not be a maximum at the equator itself. Diversity gradients for Permian brachiopods provided F. G. Stehli and C. E. Helsley (both of Western Reserve University) with distribution lines parallel to the present latitudes and therefore disagreeing with the palæomagnetic data summarized by A. E. M. Nairn (King's College, Neweastle upon Tyne). There is no obvious solution to this disagreement and investigation of the various possibilities is needed. It may be that certain of the forms had wide limits of tolerance or were not restricted by temperature. H. A. Lowenstam (California Institute of Technology) spoke of the importance of the geological time-range over which data were collected, for he showed by isotope measurements that very rapid changes in sea-water temperature had occurred in Western Australia between Sakmarian and Artinskian times.

Faunal distributions also need to be considered. J. Shirley (King's College, Newcastle upon Tyne) pointed out that faunal evidence would be more accurate at times when there were greater temperature differences between equator and poles, due to the narrowing of the climatic zones. He described a pattern of distribution of Lower Devonian marine faunas and showed its similarity to that of some Triassic faunas. At some points this conflicts with palæomagnetic evidence and at others with the present continental distribution.

The problem of growth patterns leads to a discussion of corals, and of the ideas of T. Y. Ma. Despite the fact that growth rhythms can be present in some and absent in other members of a given coral colony, the position of an equator derived from the distribution of coral localities with and without 'seasonal' growth is surprisingly similar to the appropriate palæomagnetic equator. A. G. Fischer (University of Princeton) considered that the data for one type of Silurian coral certainly did not fit the present continental positions, but were not sufficiently good to distinguish between the polar wandering, and polar wandering plus drift models.

Thirdly, palæo-deserts were discussed. Arid zones north and south of the equatorial humid belt are typical of our present climate. These nearly coincide with the zones of the Trade Winds, north-easterly up to about $20^{\circ} \mathrm{N}$. and south-easterly to about $20^{\circ} \mathrm{S}$. The presence of the easterly winds in low latitudes in contrast to the westerlies in mid-latitudes is a conseguence of the temperature gradient between the equator and the pole and of conservation of angular momentum in the atmosphere as a whole. In modern deserts two types of dunes are found, transverse, or barchan dunes and longitudinal dunes. In the former, sand is blown up the windward side and over the erest to form lee-side slopes up to $33^{\circ}$, which is the angle of repose. Successive layers of sand on the lee slopes can be revealed if dunes are wetted and then dissected, as E. D. McKee (U.S. Geological Survey, Denver) described. Similar cross-stratification is found in many sandstone rocks, which were formed by the cementation of ancient dunes, but cross-bedding, usually on a smaller scale, is also found in beds settled under water. From the direction of dip of the lee slopes of the former, the rolian sandstones, the ancient direction of the wind can be determined, and diagnostic tests to distinguish these from the latter were discussed at the Newcastle meeting. Rounding and pitting of the quartz grains by impact during transport in a desert is one, but this does not exclude the possibility of the final deposition of the sand occurring under water.

S. K. Runcorn (King's College, Newcastle upon Tyne) described the statistical distribution of directions of dip obtained from various æolian sandstones: they are interesting examples of the circular normal distribution. He also described investigations made with N. D. Opdyke (University of Rhodesia and Nyasaland) of the PermoPennsylvanian Tensleep and Casper Sandstones of Wyoming and Weber Sandstone of Utah, much of which formations show large-scale cross-bedding. The mean directions of transport, and those obtained from the Permian Coconino Sandstones of North Arizona, are consistently from the north-east. This consistency over a wide area must reflect planetary circulation. Similarly, F. W. Shotton (University of Birmingham) described his results on the New Red Sandstone of the Midlands and Scotland, which show easterly winds. Neither of these results fits to-day's general circulation, but if Europe and $\mathrm{N}$. America are restored to their positions in this period, on the basis of palæomagnetic data, the directions become those of trade winds.

J. J. Bigarella also showed similar studies of the Triassic Botucatu Sandstone of Uruguay and S. Brazil. The mean wind direction is westerly, again agreeing with palæomagnetic studies, which show the latitude and orientation of South America to have changed little since the Triassic. Bigarella's results on the Botucatu Sandstone for northeastern Brazil give results which he interprets in terms of the present wind pattern in the South Atlantic, which is not that of a trade wind.

Finally, M. G. Rutten (State University of Utrecht) suggested in discussion that the palæomagnetic latitude should be adopted as a reference and tested against other evidence of ancient climates. This, coupled with a critical search for decisive criteria, seems likely to characterize developments in this growing research field.

The Proceedings of the conference, including the discussions, will shortly be published in two volumes by J. Wiley and Sons, New York.

A. E. M. NATRN

S. K. RunCORN

\section{THE CENTRAL AGRICULTURAL RESEARCH STATION (TATE AND LYLE), TRINIDAD}

$\mathrm{D}^{\mathrm{v}}$ UE to the commercial implications of their work, industrial research organizations are seldom able to publish much of their findings, or even indicate their field of work. Such publication as is made is often long after the event.

These criticisms cannot be levelled at the annual report for 1961-62 of the Central Agricultural Research Station (Tate and Lyle), Trinidad*, published in full detail within three months of the final assessment, enabling the

* Annual Report of the Central Agricultural Research Station (Tate and Lyle), Trinidad, 1961-1962. Pp. $288+82$ appendixes. (Central Agricultural
Research Station, Carapichaima, Trinidad, 1963). findings to be applied in the 1963 season, and the reader with specific interest to examine the recorded observations. Further, the report illustrates how a small team, nine graduates and six assistants, actively led (in this case by the director, Dr. A. J. Vlitos), can complete a considerable programme in a restricted season. This is no doubt facilitated by concentration on a single crop, sugar cane, and spurred by an industry which must apply the results of research as rapidly as possible to remain profitable.

With labour rates continuously on the increase, and the sugar price largely stabilized under the Commonwealth Sugar Agreement, it is not surprising that the main research 